\title{
Reviewer Acknowledgements for English Linguistics Research, Vol. 10, No. 2
}

English Linguistics Research (ELR) would like to acknowledge the following reviewers for their assistance with peer review of manuscripts for this issue. Many authors, regardless of whether ELR publishes their work, appreciate the helpful feedback provided by the reviewers. Their comments and suggestions were of great help to the authors in improving the quality of their papers. Each of the reviewers listed below returned at least one review for this issue.

\section{Reviewers for Volume 10, Number 2}

\author{
Alina Andreea Dragoescu Urlica, University of Life Sciences, Romania \\ Li-ping Chang, National Taipei College of Business, Taiwan \\ Omer Elsheikh Hago Elmahdi, Taibah University, Saudi Arabia \\ Sawsan M.A. Ahmed, Taif University, Saudi Arabia \\ Wagdi Bin-Hady, Hadhramout University, Yemen \\ Zeineb Ayachi Ben Abdallah, Higher School of Digital Economy, Tunisia
}

\section{Best Regards,}

Camille $\mathrm{Su}$

Editorial Assistant, English Linguistics Research

Sciedu Press

$* * * * * * * * * * * * * * * * * * * * * * * * * * * * * * * * * * * * *$

Add: 9140 Leslie St. Suite 110, Beaver Creek, Ontario, L4B 0A9, Canada

Tel: 1-416-479-0028 ext. 210

Fax: 1-416-642-8548

E-mail 1: elr@sciedupress.com

E-mail 2: elr@sciedupress.org

Website: http://elr.sciedupress.com 